UDC [396+572] (082)

DOI: https://doi.org/10.30839/2072-7941.2018.149657

\title{
ANTROPOLOGICAL HORIZONS OF GENDER EQUALITY: FROM RELIGIOUS CANNONS TO BUSINESS CHALLENGES
}

\author{
(C) OLEKSENKO, R. I. \\ Tavria State Agrotechnological University (Melitopol, Ukraine) \\ E-mail: roman.xdsl@ukr.net, ORCID 0000-0002-2171-514X \\ C) ORTINA, H. V. \\ Tavria State Agrotechnological University (Melitopol, Ukraine) \\ E-mail: ortinaganna@gmail.com, ORCID 0000-0003-0266-740X \\ (C) KOLOKOLCHIKOVA, I. V. \\ Tavria State Agrotechnological University (Melitopol, Ukraine) \\ E-mail: Irinakolokolchikovairina@tsatu.edu.ua, ORCID 0000-0002- 5692-0901 \\ C SYZONENKO, O. V. \\ Tavria State Agrotechnological University (Melitopol, Ukraine) \\ E-mail: syzonenko.lena@gmail.com, ORCID 0000-0001-6808-3656
}

\begin{abstract}
Relevance of research. Any religion in the world emphasizes the woman's femininity, namely an anthropological feature that does not require similarity with the functional features of her husband. However, in turn, it has the potential of a comprehensive development of the individual as a mother, and the realization of the role of women in society. The misconceptions that maternity lifts women's potential and suppresses their personal development causes a lot of controversial issues that lead to negative manifestations of gender inequality. Negative manifestations of the perception of false positions lead to terrible structural changes in society, ruin (or shake) the foundations of the laws of motherhood, have consequences of the aging of the nation, the loss of human spiritual humanism. Women lose the opportunity to feel like a mother and transfer their love of work to work as a child. Therefore, its main base anthropological identity is reduced to zero in this case and makes a woman "uncertain" gender, which will never find its place in society. The aim of the study.It based on the study of the anthropological horizons of gender inequality within the framework of religious canons and modern trends in the manifestation of business, the loss of anthropological value of women. The author's team has proved that each of the religions of the world pays much attention to women as mothers, their roles in society with exceptional abilities and special qualities. None of the religions does restrict women in revealing these abilities, but places anthropological peculiarity on the first place of a woman-mother, guardian of the family. Religion acts as a universal anthropological phenomenon, which reveals each individual essential element characteristic of every person and emphasizes its importance for society.
\end{abstract}

Keywords:gender, inequality, woman, women's potential, business, society, public consciousness, religion. 
Statement of problem. Religion was and is a decisive motive and impulse in many socio-historical movements and processes. Adoption of Asia by Buddhism, the spread of Christianity in Europe, the expansion of Islam, the reformation of Catholicism have become in the life of mankind with milestones, which to a large extent determined the scale, pace, trends of world development. For more than two millennia, religion was the main form of social consciousness.

The coexistence of a large number of religious forms in a single cultural space, the emergence of new nontraditional religious movements and exotic individual forms of religion, the escalation of acts of terrorism and wars on religious grounds, the use of religious feelings and interdenominational relations in political technologies point to the multidimensional nature of religiosity and determines the need to study religion as a universal Anthropological phenomenon, consisting of individual essential elements, characteristic for each person, for any of the Society and Culture [1, p. 6-7]

The science of the religions of the world, about religious traditions and beliefs is one of the most open to dialogue with different branches of knowledge - sociology, philosophy, psychology, history. And the gender approach is no exception here, as evidenced by recent scientific publications in the field of religious studies. Until recently it was possible to deny any link to gender and religion. Thanks to modern interdisciplinary scientific research, it became apparent that the entire world culture, based on the opposition, is "male-female" [2, p. 143-148]

Analysis of research and publications. The topic of gender studies, namely the place and role of women in business, are quite clearly manifested in the writings of contemporary Ukrainian scholars, including T. Vlasova, Y. Maslova, T. Buherechak, R. Martynyuk, T. Martsenyuk, S. Ponomariov, I. Fedorovich and others. The theoretical and practical aspects of the evolution of society and the place of women in the business world have been considered. The problem of gender inequality in the society from the point of view of religious attitude towards the role of woman - mother is investigated, "limiting, allowing" to reveal its potential in business.

The aim of the study. It based on the study of the anthropological horizons of gender inequality within the framework of religious canons and modern trends in the manifestation of business, the loss of anthropological value of women.

\section{Presentation of the main} research material.According to Pew Research Center (PRC), the majority of countries, which supporting state religious beliefs are located in the Middle East, North Africa and Asia, and also have a small cluster of such countries in northern Europe [3]

A demographic survey conducted by the PRC in more than 230 countries showed that believers consider themselves about 5.8 billion out of 6.9 billion inhabitants of the Earth. Thus, $32 \%$ profess Christianity, $23 \%$ - Islam, Hinduism professes 15\% of the inhabitants of the planet, $7 \%$ 
follow the teachings of Buddhism, Fig. 1.

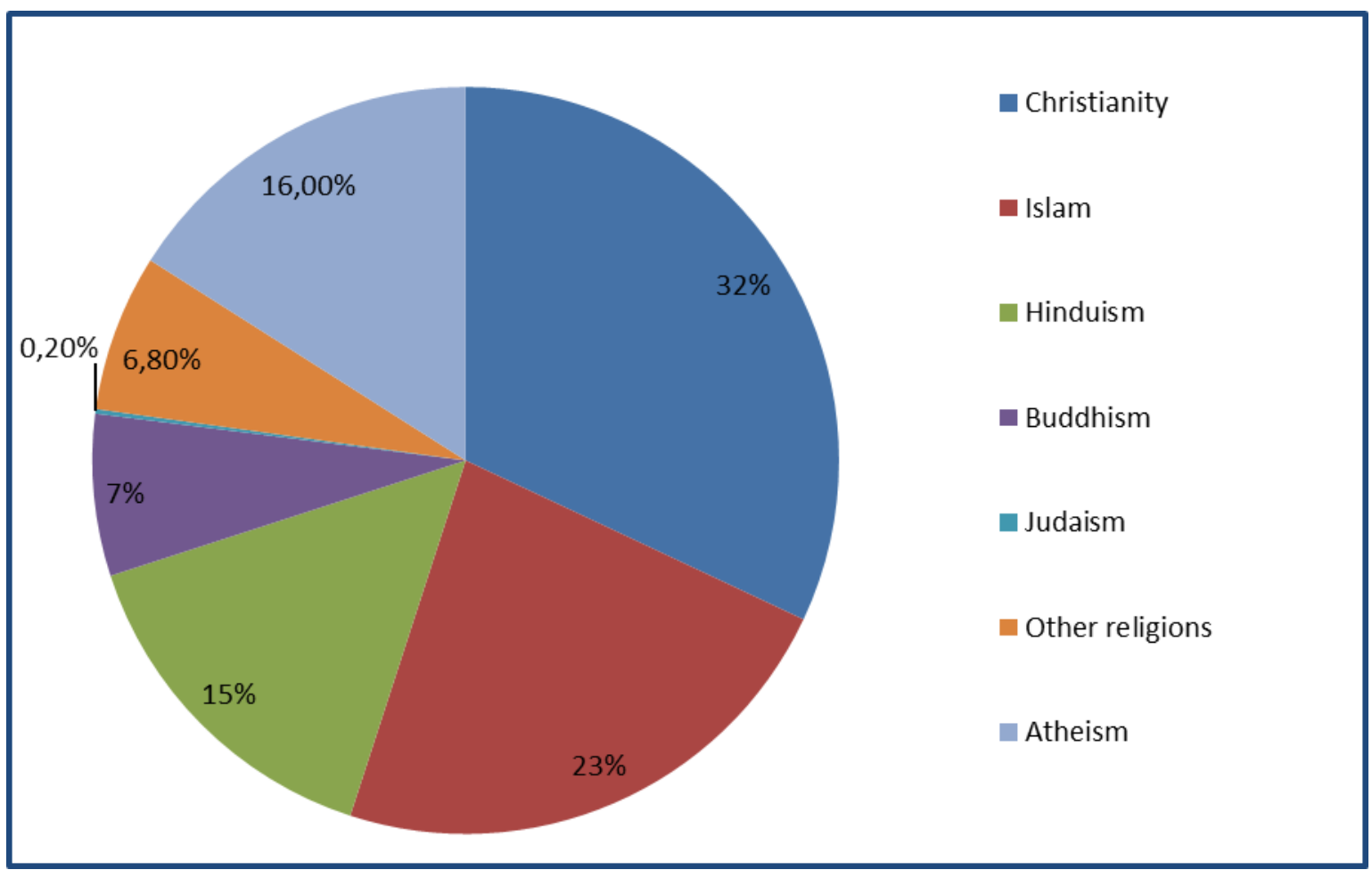

Figure 1. Religions of the world [3]

Judaism is one of the oldest monotheistic religions in the world. In his traditional doctrine here, like many other religions, the idea of a secondary woman in relation to a man (plot on the creation of Eve from the edge of Adam), her subordination to a man develops. At the same time, attention is focused on the husband's care of his wife, on respect for a woman as a mother. The sacred texts of the Jews Tanah (Old Testament) and the Torah (Pentecost Moses), written almost three thousand years ago, reflected rather contradictory trends. On the one hand, in some parts of the Old Testament, a woman acts as a slave, disenfranchised and completely subordinate to her husband. On the other hand, the Torah establishes the principle equality of men and women as the creations of God.
The place and role of women in Christianity have historically changed since the Church of the New Testament in the third century. This is especially evident in matters of marriage and official positions in some Christian denominations, churches and other organizations. Many leading roles in the organized church were forbidden to women. In the Roman Catholic and Orthodox churches only men have the opportunity to work in leading positions such as dad, patriarch and bishop. Women can serve as abbots.

Christianity, in particular Catholicism, defends in every way women in femininity. Feminism, in the sense of equalizing a woman to her husband, is categorically not accepted by Christianity. A woman does not need to look for a likeness to a man, she is in itself a person, and if 
she still realizes herself as a mother, then this is the true full-fledged life that the church trusts us [4, p. 133].

Women in Buddhism are a topic that can be addressed from different perspectives, including theology, history, anthropology and feminism. As a modern assessment of women (as well as equality) in Buddhism, Masatoshi Ueka gave a diachronic text interpretation of Buddhist texts from early Buddhism to Sutra Lotus. M. Wakey considered the terms "man" and "woman" not only biologically according to the physical characteristics of each sex, but also focused on their functional roles in the relevant society, namely, "male principle" and "women's principle". The establishment of a masculine principle equally with a woman's principle is a natural order of things. They should not exist in mutually exclusive relationships. They should not focus on one at the expense of another, since both are necessary. Establishing a true "I" will become a fact of reality for both men and women [5]

The complex relationship between women and Islamic religion is revealed both in Islamic texts and in the history and culture of the Muslim world. In the Muslim tradition, the wife is completely subordinate to her husband. The main role of a woman is limited to the family, namely reproduction of offspring [6] and child care. While the role of a man is in the financial support of the family. But if a woman shows a desire, then she can get education, work, but only with the consent of the trustee.

Sharia (Islamic law) provides for complementarity, the distinction between roles, rights and responsibilities of women and men. Most Muslim countries give women different degrees of rights regarding marriage, divorce, civil rights, legal status, dress code and education. The Arab world is historically a purely male culture, where the rule of men is the norm. Even with the advent of Islam and the recognition of women's rights, traditional elements of earlier periods still remain, which undoubtedly affect the relations between men and women in society. There is always a question where Islamic rights lie in this cultural environment. This issue raises not only in non-Arab societies, but also in the Arab society itself, especially in those cases where there is a probability of denial / violation of women's rights [14].

As we see, no society relates to a woman just like a man. The 1997 United Nations Development Program came to this conclusion. Over 60 years ago, in 1948, the UN General Assembly adopted a Universal Declaration of Human Rights, stating that every person, regardless of sex, has the right to the same freedoms. However, the 1997 report on human development suggests that no state at that time succeeded in this matter. Moreover, the level of "failure" in each country was its own. Thus, in the Nordic countries, such as Sweden, Norway and Iceland, gender inequality was and remains the smallest in our time. According to monitoring, these countries are among the least religious [7].

Based on the above, one can speak of the stereotypes that originated in religion, and then poured out beyond 
its borders. In the history of mankind, there are many examples in which the social views of society influenced its secular form, and thus became a determining factor in solving many issues, including in assessing the role of women in society.

In the first place, this has affected women's ability to carry out their professional activities. For decades, women have been struggling to take their place at work on a par with men. According to recent US census surveys, women earn only $77 \%$ of what men earn for the same amount of work. In addition to everything, it is very rare to meet women in senior positions in large companies. Women who went on maternity leave could often not resume at work because of their discriminatory or outdated notions that a woman could not achieve anything if she became pregnant and became a mother [8]

Another problem is limited mobility. In this regard, Saudi Arabia is the most striking example. In this country, women are not allowed to drive a car or ride a bicycle on public roads. The strict Islamic laws in the country prohibit women from leaving their homes without the consent of the husband, as this may encourage them to contact with strangers. And although Saudi Arabia is the only country where women are prohibited from driving, women in some other countries, for example, have restrictions on leaving the country, and even in developed countries, they can complain about such restrictions. Despite the fact that these women have a legitimate right to drive or to fly by plane, they themselves prefer not to leave the house in the evening because of the danger of rape or assault. [8]

In some countries, such as Chile and Lesotho, women do not have the right to own land and property. All documents include only male names, be it the father or the husband of a woman. If one of these men dies, then the woman has no legal rights to the property and land on which she lived and worked all his life. Therefore, very often these women remain without a roof over their heads [8].

In the scientific world, there has even been a phenomenon such as feminization of poverty. More than 1.5 billion people in the world live on less than one dollar a day, with most of these people being women. The United Nations often provides statistics that women carry out two thirds of the world's work, earning $10 \%$ of world income, but owning only $1 \%$ of their production.

The next problem is access to health care. In many developed countries, pregnant women can go to any hospital and be confident that they will receive help. According to the World Health Organization, one woman dies at the time of childbirth. This is more than 500,000 deaths a year, many of which could have been avoided if women were allowed to leave their homes when they needed treatment, and if their childbirth was attended by qualified specialists [15].

As far as education is concerned, there are also some problems caused by the inequality of the rights of men and women. Most children who do not go to school today are girls. And two thirds of illiterate people in the world are also women. In developing countries, girls are often taken away 
from school in order to help them do their homework. Or terminate their studies due to marriage. In some families there is no way to teach all children and, therefore, in this case, the preference is given to the education of the boy, not the girls.

Analysts often argue that many of these problem issues could have been solved if women had a higher level of political participation. Despite the fact that women make up half of the world's population, they only occupy $22 \%$ of seats in parliaments around the world. The absence of women can be traced at all levels of government local, regional, and national. But why is it so important for women to take part in politics? Studies that looked at the role of women in leadership positions in Bolivia, Cameroon and Malaysia found that women, unlike men, were more prone to invest in family spending, community resources, health care, education, in shaping priority spending items and overcoming poverty. As a rule, women are less represented in business and entrepreneurship and are mainly employed in healthcare, social welfare, education and administrative work.

The World Economic Forum team, in its Annual Report Global Gender Gap Report, presented countries ranking on the equality of articles. In 2017, 144 states participated in the study, each of which assessed the nation's desire for equality of articles based on four key criteria: economic attractiveness and opportunities for women, education, and sex ratio at birth and life expectancy, and women's participation in political life society [9].
According to the listed indicators, the leader of the rating is Iceland (9 consecutive times), with a minimum gap between the participation of men and women in all important areas of public life at $87.8 \%$ (where $100 \%$ means absolute equality of the articles). Since 2006, the country has managed to overcome $10 \%$ of internal gender inequality. The three leaders also included Norway (83\%) and Finland $(82.3 \%)$. The worst situation with gender equality is observed in Syria (56.8\%), Pakistan (54.6\%), and Yemen (51.6\%). Ukraine ranked 61st with a score of $70.5 \%$, Russia 71 (69.6\%), Belarus - 26 (74.4\%), Armenia - 97 (67.7\%), and Georgia 94th place $(67,9 \%)$ [9].

Today women occupy $22 \%$ of parliamentary armchairs in the world. However, this indicator is significantly different when comparing continents and countries. For example, in the parliaments of Europe, the largest number of women is in Sweden, Belgium, Finland, Iceland, Norway (40-44\%). And the smallest figure in Hungary, Romania, Cyprus and Malta (10-13\%). However, higher rates of sexual equality are recorded in Europe and in Africa and South America. Although the rates are very different there: from $58 \%$ in Rwanda to $8 \%$ in the Democratic Republic of the Congo and $6 \%$ in Nigeria.The situation in South America is similar: in Bolivia, women account for more than half of the seats in the parliament (52\%), while in Brazil only $11 \%$ [10].

Entrepreneurship plays an important role in creating new jobs, implementing innovation and stimulating growth both in developing 
countries and in developed countries. As the survey shows, the share of women-owned enterprises in general is approximately $30 \%$ of the total number of enterprises in both the member-countries of the Organization for Economic Cooperation and Development and in developing countries. Moreover, in the studied countries there are significant differences in the indicators of female entrepreneurial activity, starting with $3 \%$ in Germany, Jordan, Italy and France and up to $37 \%$ in Senegal.

It is possible to separately distinguish five countries in which women participate in economic activity at the level of men. These are countries of high parity and come from two regions: Asia (Indonesia, the Philippines and Vietnam) and Latin America (Mexico and Brazil). Women in these countries have at least $60 \%$ of the rights given to men. The gap between men and women is greatest in Jordan, and the female entrepreneurship is about one-quarter of men's [11].

Thus, the so-called revaluation of values takes place, which in turn leads to a rethinking of the importance of family and marital relationships in the life of the weak. It turns out that the task of women in the modern world is primarily the achievement of success in work, career growth, material independence, and only then the status of the wife and mother.

Ronald Inglehart, using the "European Values Survey" and "World Values Survey", has demonstrated the link between the prevalence among the population of certain values with the level of modernization of society, the level of its economic development and democratization. It has been shown that in Ukraine and neighboring countries, in the first place, there are material values or values of survival (as opposed to the values of selfexpression), as well as secular-rational values (as opposed to the values of tradition). Most European countries have a high significance of selfexpression values [12].

There is a "declaration of indifference to eternal durability in favor of the desire for immediate" in world reality. "Flux of the present" this definition of our time gives $\mathrm{Z}$. Bauman, one of the most interesting interpreters of our time. If "solid" reality was the era of mutual obligations, then "fluid", "fluid" modernity - this is an era of separation, impermanence, easy escape and hopeless persecution. M. Kundera portrayed "the unbearable ease of being" as the center of the tragedy of modern life. Indeed, according to S. Baumann, in the "fluid" present-day, those who are most elusive and free to move without warnings are ruled. "Instant", "intolerance", "short-term", "mobility" are a set of synonymous words that reflect the state of our world, the essence of our lives. Long-term relationships go into short-term, longlived family life is replaced by temporary coexistence, fundamentalism, depth is replaced by superficial, labor relations undergo changes, transformed understanding of education and human development [12].

Sociological research among young people fixes changes in value benefits: the importance of individual 
orientations increases. For some, it is rest and entertainment, for others it is a beautiful and comfortable life; for the third one, it's proper well-being and a career, for the fourth one - the main values of the well-being of the family, health, good (well-paid) work remain. These conclusions confirm the tendency towards the growth of ideological and ideological pluralism, multivariateness, "mosaicism" and fragmentation of world outlook. The positions of those for whom the values of property and property status become the most important are realized, realized through the prism of utilitarianism, individual preferences and goals. For many, the situation is a value gap where people do not know what they want or what they want to do.

The ideology of consumer society, when the main value is money and power, leads to the substitution of universal values that confessed in different ages, among different peoples, to false values, to distort the basic concepts. [Bychkov A.V., Mikushina T.N., Skuratovskaya M.L., IlinaYe.Yu., 2015]

Replacement of concepts occurred in the relationship between a man and a woman. Woman, taking on habits, deeds and lifestyle from a strong sex, moves away from femininity and becomes courageous. Earlier, the mission of the woman was to marry, to the birth and rearing of children. Families were many children, and today women give birth to one or two children, and after a year go to work. Occasionally, when a wife earns more, she occupies a higher position, and her husband takes home troubles. Interestingly, the femininity of the weak sex does not go unnoticed. She is tried by men, but in distorted form. Softness of girls goes into flesh, attention to details is expressed in pettyness. Freedom in private life has increased the number of divorces.

In 2017 the population of Europe exceeded 511.8 million people. Since 1975, the population of European countries has increased by 60 million, and in the last 10 years (2007-2017) by 13.5 million inhabitants. However, this was due to immigrants. Also, the report noted disproportion in the number of inhabitants of individual countries. In the four most populous states (Germany - 82.8 million, France - 67 million, Great Britain - 65.8 million, Italy - 60.5 million), $54 \%$ of the entire population of the EU (276.2 million people) live in total. Instead, in the three least developed countries (Luxembourg, Cyprus and Malta) there are only 1.8 million inhabitants, which is $0.3 \%$ of the total population. Meanwhile, the natural population growth in the EU over the past 20 years is almost entirely the result of fertility in France, the United Kingdom and Spain. There over this period more than 23.5 million people were born, which accounts for $82 \%$ of the population growth for all EU countries. But 8 countries only note the birth rate decline. The largest is in Romania (-2.94 million citizens), then alternately in Bulgaria (-1.23 million), Lithuania (-740 thousand), Poland (666 thousand), Hungary (-502 thousand), Latvia (-494 thousand), Croatia (-378 thousand) and Estonia (90 thousand) [13]

In 1995, demographic growth in Europe was more a consequence of migration than fertility. In 2015 and 
2016 this figure was $100 \%$, as the total natural population growth in the EU countries was negative. In 2000, 1,03 million immigrants were 305,000 people, in 2013 - 1,76 million immigrants and 76 thousand peoples. In 2016, 1.22 million immigrants arrived in Europe, and the natural growth rate of the population was 15.8 citizens (was negative). Countries where deaths are higher than peoples are Germany and Italy [13]

According to the data provided by the IPF, every fifth of Europeans is a person older than 65 years. In general, they are 97.7 million in Europe and they account for almost $20 \%$ of society. Since 1986, this number has grown by more than $6 \%$, while the number of young people under 15 has decreased by 23 million, now accounting for $15.6 \%$ of European society. As many as 25 million Europeans - people over 80 years old. In other parts of the world - reverse trends. In the United States, young people under 15 years old account for $19 \%$, and people over 65 years old $15.03 \%$. In China, this ratio is $17.7 \%$ versus $10.02 \%$. In European countries, the highest percentage of young people (under 15 years of age)is registered in Ireland $(21.9 \%$ of society), France (18.5\%), and Great Britain (17.7\%). Instead, the youngest are young people in Bulgaria (14\%), Italy $(13.7 \%)$ and Germany (13.2\%). There are more people over 65: $22 \%$ and $21.1 \%$ in Italy and Germany. Such residents have the lowest $(14.2 \%)$ in Ireland [13]

In 2015, the world birth rate was 2.5 children per woman, while in Europe it is barely 1.6. The average age of mothers is also growing. In 1980, women gave birth to their first child, having an average age of 27.1 years, and by 2016 this figure increased to 30.6 years of life. The Irish (32.1) and Spaniards (32 years) are weaned at the latest on children's birth [13]

In Europe, the number of spouses decreases each year: from 3.48 million in 1975 to less than 2.2 million in 2015. This means that in Europe in 1975 there were about 9.5 thousand marriages, and in 2015 they were registered only 6 thousand a day. And this happens despite the population growth of the continent by almost 60 million over these decades. The ratio of marriages per 1000 inhabitants decreased from 7.7 in 1975 to 4.2 in 2015. In China, for example, it is 9.6, and in the US - 6.9. On the whole, on the European continent, the marriage rate dropped by almost 2.26 points. The strongest decrease was recorded in France, where the indicator decreased by as much as 6.2 points. The only country where the number of spouses has grown is Sweden. Now in Europe, 4 out of 10 children are born out of wedlock. Between 1990 and 2015, the number of non-marital peoples increased from $18.05 \%$ to $42.5 \%$ and amounted to more than 2.15 million by 2015 . This means that in the EU countries, every year, out of 14.1 thousand born children, 5.94 thousand came to the world outside of marriage. Also, in the EU there is a big difference in the age of newlyweds. According to statistics, men are married most recently in Sweden and Spain (respectively, 36.2 years and 34.9 years), and most of all - in 
Lithuania and Poland (28.9 and 29.3). Women who are married the worst live in Sweden (33.6 years) and Spain (2.7 years), but most of all - in Romania (26.8) and Poland (26.9) [13]

The number of divorces in the EU has grown from more than 615.3 thousand in 1975 , to more than 1.01 million in 2010. Since then, the figure has been gradually decreasing and by 2015 it has been incomplete 946 thousand. This means that on average in Europe one spouse is divorced every 30 seconds, and divorce court judgments number over 2,59 thousand. This is recognized as the first reason for the lack of family stability. . Between 1980 and 2015, more than 30.8 million divorces occurred in Europe. The largest number of divorces has increased in Spain, Italy, Germany - and, albeit surprisingly, in Poland. In addition, young couples are increasingly divorced. According to data from 2015 , every seven couples decide to divorce less than after 5 years of marital communication and a quarter of spouses who break up, are links lasting 5-9 years. According to the authors of the report, in 1975 in Europe one of eight spouses collapsed, and in 2015 - one of three. According to statistics, the largest number of divorces is in Portugal (72\%), Luxembourg (66\%) and Belgium (61\%), and the least in Malta (12\%), Ireland (15\%) and Romania (25\%). Absolute leader in divorce in Europe - Ukraine, there are 5.3 per 1000 inhabitants [13]

In the EU, only three out of 10 workers can boast of a flexible work schedule that facilitates the reconciliation of family life with professional duties. Therefore, among the parents, and especially among women, the "incomplete rate" is more popular. She was given the advantage of $79 \%$ of women (33.7 million out of 42 million employees) and $82 \%$ of those with children. The highest percentage of part-time women is registered in Luxemburg (85.5\%), Germany $(83.8 \%)$ and Malta $(83 \%)$. The least of them are in Romania (51.4\%), Bulgaria (53.7\%) and Cyprus (58.1\%). $97 \%$ of the postpartum leave lasts less than one month. But in Europe, about $97.5 \%$ of mothers take maternity leave of more than 12 months [13]

On the one hand, the achievement of gender equality gives women the opportunity to study, work, build a career, develop and realize themselves on a par with men, which is a positive factor, especially in the countries of the East, which traces a high gender incidence rate. However, on the other hand, in the West countries there is an absolutely opposite situation. The explicit emancipation of women is manifested in global negative phenomena, such as the elimination of family values, lower birth rates and increased mortality on the planet, the aging of the nation.

Conclusion.Any religion in the world emphasizes femininity, its anthropological peculiarity that does not require similarity with the functional characteristics of a man, but in turn has the potential for the full development of both mother and the role of women in society.

Pope John Paul II believed that it was impossible to solve a woman's question, not taking into account the 
role of women in the family, or foolishly rejecting the fact that every new life should be entrusted with the protection and care of a woman who carries this life in her womb. Respect for the order of things, which is established by nature, requires the abandonment of the false representation that motherhood suppresses a woman that the service of the family, and especially children, prevents a woman from disclosing as a personality, and for women in general, to influence society $[4, \mathrm{p}$. 133]

The misconceptions that maternity lifts women's potential and suppresses their personal development causes a lot of controversial issues, which leads to negative manifestations of gender inequality.

Negative manifestations of the perception of false positions lead to terrible structural changes in society, undermine the foundations of the laws of motherhood, have consequences of the aging of the nation, the loss of human spiritual humanism. Women lose the opportunity to feel like a mother, but they carry the level of their love for work as a child. As a result, her main base anthropological affiliation is reduced to zero and makes a woman "uncertain" gender who will never find her place in society.

\section{REFERENCES}

1. Larionova, V. K. (2004). Filosofiya religiyi. Ivano-Frankivsk: Vidavnitstvo «Gostinets», 148.

2. Maslova, Yu. P. (2010). Religiyno-mifologichne pidrruntya gendernikh stereotipiv. Seriya «Istorichne religieznavstvo», 3, 143-148.

3. Ignatov, S. (2017). Bolee $20 \%$ stran mira imeyut ofitsialnuyu gosudarstvennuyu religiyu. Available at: https://www.sedmitza.ru/text/7549104.html

4. Ioann, P. II (2004). Idite s mirom. Dar bessmertnoy lyubvi. Moscow: OOO Izdatelskiy dom"Sofiya", 208.

5. Masatoshi, U. (2001). Gendernoeravenstvo v buddizme. New York: PiterLang, 191.

6. Gorshunova, O. V., Peshkova, S. A. (2013). Fertilnost i sakralnoe zhenskoe nachalo v sredneaziatskikh tselitelskikh i ritualnykh praktikakh. Meditsinskaya antropologiya i bioetika, $1(5)$.

7. Interaktivna karta religiynosti svitu. Available at: https://risu.org.ua/ua/index/all_news/community/social_questioning/69836/

8. Primery gendernogo neravenstva vovsem mire. Available at: https://www.infoniac.ru/news/Primery-gendernogo-neravenstva-vo-vsem-mire.html

9. Sostavlen reyting stran po urovnyu gendernogo ravenstva (2017). Available at: https://livingintravels.com/sostavlen-rejting-stran-po-urovnyu-gendernogo-ravenstvu

10. Martsenyuk, T. (2015). Genderna rivnist i dolya zhinok v parlamentakh svitu. Available at: http://khpg.org/index.php?id=1437182774 [in Ukrainian]

11. Global Entrepreneurship Monitor 2016/2017. Report on Women's Entrepreneurship. Available at: https://www.babson.edu/Academics/centers/blank-center/globalresearch/gem/Documents/GEM\%202016-2017\%20Womens\%20Report.pdf [in English]

12. Bychkov, A. V., Mikushina, T. N., Skuratovskaya, M. L., Ilina, Ye.Yu. (2015). «Doktrina Vysokoy Nravstvennosti». Mezhdunarodnoe Obshchestvennoe Dvizhenie «ZA NRAVSTVENNOST!» Available at: http://www.z-n.center/index.htm

13. Stanovyshche simi v Yevropi: statystyka, shcho bie na spolokh. CREDO. Available at: http://credo.pro 
14. Omer Nasukhi Bilmen, (2001). Bolshaya islamskaya nauchnaya entsiklopediya. Omer Nasukhi Bilmen. Neftechala.

15. Brak informatsiyi, prav ta hroshei. Chomu zhinky vse shche vmyraiut pid chas polohiv. Available at: https://nv.ua/ukr/world/countries/brak-informatsiji-prav-i-hroshejchomu-zhinki-vse-shche-vmirajut-pid-chas-polohiv-2496435.html

ОЛЕКСЕНКО, Р. І. - доктор філософських наук, професор, професор кафедри маркетингу, Таврійський державний агротехнологічний університет (Мелітополь, Україна)

E-mail: roman.xds1@ukr.net ORCID 0000-0002-2171-514X

КОЛОКОЛЬЧИКОВА, І. В. - кандидат економічних наук, доцент, доцент кафедры маркетингу, Таврійський державний агротехнологічний університет (Мелітополь, Україна)

E-mail: Irinakolokolchikovairina@tsatu.edu.ua ORCID 0000-0002- 5692-0901

ОРТІНА, Г. В. - доктор наук $з$ державного управління, доцент, в.о. завідувача кафедри публічного управління, адміністрування та права», Таврійський державний агротехнологічний університет (Мелітополь, Україна)

E-mail: ortinaganna@gmail.com ORCID 0000-0003-0266-740X

СИЗОНЕНКО, О. В. - викладач кафедри публічного управління, адміністрування та права, Таврійський державний агротехнологічний університет (Мелітополь, Україна)

E-mail: syzonenko.lena@gmail.com ORCID 0000-0001-6808-3656

\section{АНТРОПОЛОГІЧНІ ГОРИЗОНТИ ГЕНДЕРНОЇ НЕРІВНОСТІ: ВІД РЕЛІГІЙНИХ КАНОНІВ ДО БІЗНЕСОВИХ ВИКЛИКІВ}

Анотація. Актуальність дослідження. У статті досліджуються антропологічні горизонти гендерної нерівності в рамках релігійних канонів та сучасних тенденцій прояву бізнесу, втрати антропологічної цінності жінок. Постановка завдання. Концептуалізація ролі жінки в суспільстві та вплив на неї релігійної приналежності; виявлення схожостей та відмінностей ролі жінок у релігіях світу; виявлення хибних стереотипів які склалися в релігії та вийшли за ії межі. Аналіз останніх досліджень і публікацій. Темою гендерних досліджень, а саме місце та ролі жінки в бізнесі та вплив на неї з точки зору релігії достатньо виразно проявляються у працях сучасних українських вчених, серед яких варто відзначити: Т. Власова, Ю. Маслова, Т. Бурейчак, Р. Мартинюк, Т. Марценюк, С. Пономарьов, І. Федорович та інші. Виділення недосліджених частин загальної проблеми. В основі дослідження висвітлено теоретичні та практичні аспекти еволюції суспільства та місця жінки в світі бізнесу та вплив релігії на ці трансформації. Методологія. Основою дослідження виступає антропологічний підхід, який базується на принципах об'єктивності й цілісності, а також на комплексі загально-філософських, історичних, загальнонаукових та спеціальних методів дослідження, що дозволило забезпечити обгрунтованість i достовірність наукових результатів щодо гендерної нерівності жінок в бізнесі та вплив на неї релігійних догм.

Виклад основного матеріалу. У роботі розглянуто роль жінки в суспільстві та вплив на її життя та розвиток, як особистості, релігійної приналежності. Досліджено питання гендерної нерівності в суспільстві з точки зору релігійного відношення до ролі жінки - матері, «обмежуючи, дозволяє» розкривати свій потенціал у бізнесі.

Висновки. Будь-яка релігія світу підкреслює жіночність, іiі антропологічну особливість яка не потребує схожості за функціональними особливостями з чоловіком, але в свою чергу має можливості всебічного розвитку як матері так і ролі жінки в суспільстві. Хибні уявлення про те, що материнство нівелює жіночий потенціал та пригнічує іiї особистий розвиток викликають безліч дискусійних питань, що призводить 
до негативних проявів гендерної нерівності. Негативні прояви сприйняття хибних позицій призводять до жахливих структурних змін в суспільстві, розхитують основи законів материнства, мають наслідки старіння нації, втрати людьми духовного гуманізму. Жінки втрачають можливість відчути себе матір'ю, та переносять рівень своєї любові на працю як на дитину. В результаті іiі основна базова антропологічна приналежність зводиться до нуля та робить жінку «невизначеної» статі, яка ніколи не знайде своє місце в суспільстві.

Ключові слова: гендер, нерівність, жінка, жіночий потенціал, бізнес, суспільство, суспільна свідомість, релігія.

ОЛЕКСЕНКО, Р. И. - доктор философских наук, профессор, профессор кафедры маркетинга, Таврический государственный агротехнологический университет (Мелитополь, Украина) - доктор философии, профессор, Таврический государственный агротехнологический университет (Мелитополь, Украина)

E-mail: roman.xdsl@ukr.net ORCID: 0000-0002-2171-514X

КОЛОКОЛЬЧИКОВА, И. В. - кандидат экономических наук, доцент, доцент кафедры маркетинга, Таврический государственный агротехнологический университет (Мелитополь, Украина)

E-mail: Irinakolokolchikovairina@ tsatu.edu.ua ORCID: 0000-0002- 5692-0901

ОРТИНА, А. В. - доктор наук государственного управления, доцент, и.о. заведующая кафедры публичного управления, администрирования и права, Таврический государственный агротехнологический университет (Мелитополь, Украина)

E-mail: ortinaganna@gmail.com ORCID: 0000-0003-0266-740X

СИЗОНЕНКО, Е. В. - преподаватель кафедры публичного управления, администрирования и права, Таврический государственный агротехнологический университет (Мелитополь, Украина)

E-mail: syzonenko.lena@ gmail.com ORCID; 0000-0001-6808-3656

\section{АНТРОПОЛОГИЧЕСКИЕ ГОРИЗОНТЫ ГЕНДЕРНОГО НЕРАВЕНСТВА: ОТ РЕЛИГИОЗНЫХ КАНОНОВ ДО БИЗНЕСОВЫХ ВЫЗОВОВ}

Аннотация. Актуальность исследования. В статье исследуются антропологические горизонты гендерного неравенства в рамках религиозных канонов и современных тенденций проявления бизнеса, потери антропологической ценности женщин. Постановка задачи. Концептуализация роли женщины в обществе и влияние на нее религиозной принадлежности; выявление сходства и различий роли женщин в религиях мира; выявления ложных стереотипов сложившихся в религии и вышли за ее пределы. Анализ последних исследований и публикаций. Темой гендерных исследований, а именно место и роли женщины в бизнесе и влияние на нее с точки зрения религии достаточно отчетливо проявляются в работах современных украинских ученых, среди которых стоит отметить Т. Власова, Ю. Маслова, Т. Бурейчак, Р. Мартынюк, Т. Марценюк, С. Пономарев, И. Федорович и другие. Выделение неисследованных частей общей проблемы. В основе исследования отражены теоретические и практические аспекты эволюции общества и места женщины в мире бизнеса и влияние религии на эти трансформации. Методология. Основой исследования выступает антропологический подход, основанный на принципах объективности и целостности, а также на комплексе в-философских, исторических, общенаучных и специальных методов исследования, что позволило обеспечить обоснованность и достоверность научных результатов по гендерного неравенства женщин в бизнесе и влияние на нее религиозных догм. 
Изложение основного материала. В работе рассмотрена роль женщины в обществе и влияние на еe жизнь и развитие, как личности, религиозной принадлежности. Исследован вопрос гендерного неравенства в обществе с точки зрения религиозного отношения к роли женщины - матери, «ограничивая, позволяет» раскрывать свой потенциал в бизнесе.

Выводы. Любая религия мира подчеркивает женственность, ее антропологическую особенность не требующая сходства по функциональным особенностям с мужем, но в свою очередь имеет возможности всестороннего развития как матери так и роли женщины в обществе. Заблуждения о том, что материнство нивелирует женский потенциал и подавляет ее личностное развитие вызывают множество дискуссионных вопросов, что приводит к негативным проявлениям гендерного неравенства.Негативные проявления восприятия ложных позиций приводят к ужасным структурных изменений в обществе, расшатывают основы законов материнства, имеют последствия старения нации, потери людьми духовного гуманизма. Женщины теряют возможность почувствовать себя матерью и переносят уровень своей любви на труд как на ребенка. В результате ее основная базовая антропологическая принадлежность сводится к нулю и делает женщину «неопределенной» пола, никогда не найдет свое место в обществе.

Ключевые слова: гендер, неравенство, женщина, женский потенциал, бизнес, общество, общественное сознание, религия.

Стаття рекомендована до публікачї д.філософ.н., проф. В.Г.Воронковою (Запоріжжя, Украӥна)

Надійшла до редколегї: 11.09.2018

Прийнята до друку: 16.09.2018 